\title{
Correction to: The stories groups tell: campaign finance reform and the narrative networks of cultural cognition
}

\author{
Aaron Smith-Walter ${ }^{1}$ (D) Michael D. Jones ${ }^{2} \cdot$ Elizabeth A. Shanahan $^{3} \cdot$ Holly Peterson $^{4}$
}

Published online: 14 August 2019

(c) The Author(s) 2019

\section{Correction to: Quality \& Quantity https://doi.org/10.1007/s11135-019-00884-8}

The article "The stories groups tell: campaign finance reform and the narrative networks of cultural cognition", written by "Aaron Smith-Walter, Michael D. Jones, Elizabeth A. Shanahan, Holly Peterson", was originally published electronically on the publisher's internet portal https://link.springer.com/article/10.1007/s11135-019-00884-8 on 17 May 2019 without open access.

With the author(s)' decision to opt for Open Choice, the copyright of the article changed on 14 August 2019 to (C) The Author(s) 2019 and the article is forthwith distributed under the terms of the Creative Commons Attribution 4.0 International License (http://creativeco mmons.org/licenses/by/4.0/), which permits use, duplication, adaptation, distribution and reproduction in any medium or format, as long as you give appropriate credit to the original author(s) and the source, provide a link to the Creative Commons license and indicate if changes were made.

The original article has been corrected.

The original article can be found online at https://doi.org/10.1007/s11135-019-00884-8.

Aaron Smith-Walter

Aaron_smithwalter@uml.edu

Michael D. Jones

MichaelJones@oregonstate.edu

Elizabeth A. Shanahan

shanahan@montana.edu

Holly Peterson

hollypeterson@gmail.com

1 Department of Political Science, University of Massachusetts Lowell, Lowell, USA

2 School of Public Policy, Oregon State University, Corvallis, USA

3 Department of Political Science, Montana State University, Bozeman, USA

4 Department of Political Science, University of South Alabama, Mobile, USA 
Open Access This article is distributed under the terms of the Creative Commons Attribution 4.0 International License (http://creativecommons.org/licenses/by/4.0/), which permits unrestricted use, distribution, and reproduction in any medium, provided you give appropriate credit to the original author(s) and the source, provide a link to the Creative Commons license, and indicate if changes were made.

Publisher's Note Springer Nature remains neutral with regard to jurisdictional claims in published maps and institutional affiliations. 